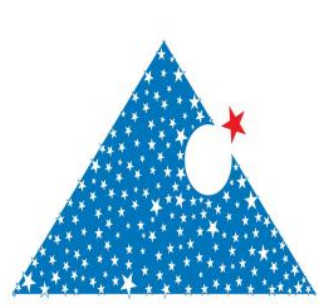

\title{
Sıcak Dövme Sanayisinde Çalışanların Titreşimle İlgili Risklerden Korunma Çalışmaları
}

\author{
İsmail ÜNVER, Yahya BOZKURT* \\ Marmara Üniversitesi, Fen Bilimleri Enstitüsü Metal Eğitimi Anabilim Dalı, Göztepe Kampüsü, 34722, \\ Kadıköy/ISTANBUL, i.unver@outlook.com \\ Marmara Üniversitesi, Teknoloji Fakültesi, Metalurji ve Malzeme Mühendisliği Bölümü, Göztepe Kampüsü, \\ 34722, Kadıköy/ISTANBUL, ybozkurt@marmara.edu.tr
}

Received/Geliş: 12.12 .2017

Revised/Düzeltme: 16.02 .2018

Accepted/Kabul: 19.02 .2018

Öz: Çeliğin belli bir sıcaklık altında tavlanarak basınç altında şekil verilmesi olayına sıcak dövme denilmektedir. Bu çalışmada, dövme sanayinde karşı vuruşlu çekiç tezgâhlarının, operatör üzerinde meydana getirdiği titreşim değerlerini önleme çalışmaları, tezgâhlardan meydana gelen ölçüm değerleri ile beraber iş sağlığ 1 ve güvenliği açısından titreşim maruziyet değerleri yönetmelikte belirtilen değerler ile k1yaslanarak incelenmiştir. İstanbul' da faaliyet gösteren bir dövme işletmesinde iç ortam titreşim ölçümleri yapılmıştır. Maruziyet değerlerinin, tezgâh operatörlerine zarar vermeyecek değerlere düşürmek için gerekli önlemlerin alındığı görülmüştür. DG40 tezgâh gurubunda tüm titreşimi için ölçülen değer 0,035 $\mathrm{m} / \mathrm{s}^{21}$ dir. İşletmenin iş sağ lı̆̆ 1 ve güvenliği kültürü oluşturma çabalarının devam ettiği gözlemlenmiştir. İş sağlığı ve güvenliği konusunu büyük oranda benimsemiş olan bir işletmenin gerekli önlemleri alması sayesinde iş̧̧ilerde titreşime dayalı meydana gelen maruziyet değerlerinin minimum seviyelere çekilmiş olduğu görülmüsştür. İşs sağlığı ve güvenliği kapsamında meslek hastalıkları ve iş kazalarının önlenmesi için proaktif yaklaşımlar her işletmenin öncelikli konuları arasında olması gerekmektedir.

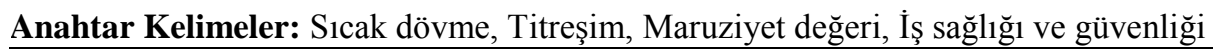

\section{Vibration Risk Prevention Activities of Employees in Hot Forging Industry}

\begin{abstract}
Tempering the steel under a certain temperature and shaping it under pressure is called hot forging. In this study, studies to prevent the vibration values caused on the operator by the counter impact hammer workbenches in the forging industry., in addition to the general measurement values were compared and examined together eith the values stated in the regulations in terms of occupational health end safety. Internal environment vibration measurements were carried out at a forging establishment that operates in Istanbul. It was observed the required precautions were taken to reduce the exposure values to the values which were not harmful for the workbench operators. In scope of DG40 workbench group, the value measured for whole body vibration is $0,035 \mathrm{~m} / \mathrm{s}^{2}$. It was observed the establishment continued the efforts to create a culture of occupational health and safety. It was observed the ecposure values caused by the vibraition on the workers were reduced to the minimom levels as the required precautions were taken by an establishment that adopted, to a significant extent, the occupational health and dafety subject. proactive approaches must be among the high-priority subjects of each establishment in order to prevent the occupational helath and safety.
\end{abstract}

Keywords: Hot forging, vibration, exposure values, business health and job security 


\section{Giriş}

Plastik şekillendirilmede malzeme katı halde, hacim değişikliğine uğramadan, kristal yapı özelliklerini koruyarak ve kırılma gibi herhangi bir süreksizlik yaratmadan kalıcı olarak şekil değiştirmektedir. şekillendirme işlemlerinde gereç olarak kalıplardan yararlanılmaktadır. Kalıpların malzeme ile doldurulması (kalıbın belirlediği şeklin malzemeye verilmesi) malzeme katı halde olduğundan yüksek gerilmelere, dolayısıyla kuvvetlere ihtiyaç göstermektedir. Dolayısıyla plastik şekillendirmede malzemeyi süreksizlik yaratmadan şekillendirebilmenin (malzeme özellikleri) yanı sıra gerekli kuvvet ve enerjinin de sağlanması (mekanik analiz) ve bunların önceden belirlenebilmesi çok önemlidir[1]. En eski üretim yöntemlerinden biri olan ve günümüzde de endüstride çok önemli bir yeri bulunan dövme, basma kuvvetlerinin etkisi ile tavlama sıcaklığında malzemenin kalıcı olarak şekil değiştirme işlemidir [2,3]. Günümüzde, dövme ile üretilen ürünlerin yüksek mukavemetli ve ağırlığının azaltılarak üretilebilmesi için, çeliklerin dövme yöntemi ile üretilmesi güncel bir çözüm olarak önem arz etmektedir. Sıcak şekil verme yöntemi ile çeliğin işlenmesi esnasında dövülecek çelik, ostenit sıcaklığının üzerindeki sıcaklıklarda 1sıtıldıktan sonra soğumadan kalıp içerisinde şekil verilirken martenzit yapı elde etmek için şekil verme işlemi bitince hızla soğuma işlemi gerçekleştirilir [4]. Sıcak dövme ile şekil verme işleminin birçok üstünlüğü vardır. Parçanın imal edilmesi için düşük kuvvet ve güç gerektirmesi bu yöntemle yapılacak üretimin üstünlüklerinden bir k1smı olup bu üstünlükler çelik imalatında hizmet veren şirketleri sıcak dövme yöntemini kullanmaya itmiştir. Birçok endüstri kolunda kullanılan binlerce dövme parçası, çeşitli malzemelerden üretilmektedir. Bunlar, yüksek nitelikler beklenen ve genellikle kritik yüklenme durumları gösteren çelik parçalar olmaktadır. Makine, motor ve uçak sanayisi için hazırlanan parçalar, dövme sanayisinde önemli bir kapasiteye sahiptir [5]. Dövme yöntemi, enerjiye dayalı bir işlem olup, belirli toplam şekil değiştirme işinin çelik parçaya iletilip son şekil elde edilinceye kadar darbe etkisi sürdürülmektedir. Basma işleminde ise aynı amaçla basınç uygulanmakta ve bu işlem kuvvete dayalı olmaktadır [6]. Çalışma hayatında, kişinin sağlığına olumsuz yönde etki bırakan birçok kriter söz konusudur. $\mathrm{Bu}$ kriterler; psiko-sosyal, kimyasal, fiziksel, tozlar, ergonomik koşullar, biyolojik koşullar olarak sınıflandırılabilir. Kişinin çalışırken titreşime maruz kalması bu kriterler arasında fiziksel risk faktörleri ismi ile yer almaktadır. Titreşim, yapılan işin çeşidine göre, çalışanların bedeninde el-kol bölgesinde rahatsızlıklara sebep olabileceği gibi tüm bedeni de etkileyebilmektedir. Çalışanların maruz kaldığı titreşimin büyüklüğü; frekansı, mesai saatlerindeki süresi ve meslekte geçirdiği çalışma süresi vb. gibi faktörlere bağlıdır. Çalışma hayatı içerisinde insanların yapmış olduğu meslekte maruz kaldığı el-kol ve tüm vücut vibrasyonunun insan sağlı̆̆ına olan etkileri farklıdır. Endüstride, taş ocağı, sıcak dövme, maden işleri, yol ve yapı işlerinde, orman ve zirai alanda, kuryeler gibi devamlı iki tekerli taşıt kullananlarda ve basit olarak kullanılabilen ev aletlerinde (şarjlı veya elektrikli matkaplar), el-kol vibrasyonuna mesleki veya özel maruziyet olduğu görülmektedir. Bir enerjiye sahip olan aletlerin etrafa yaymış olduğu, özellikle parmaklar aracılığ 1 ile insan vücuduna iletilen mekanik enerjiye el-kol vibrasyonu denilmektedir. El-kol vibrasyonuna çokça maruz kalan çalışanlarda; damarlarda, sinirlerde, kaslarda, titreşime maruz bırakılan kemiklerde hasarlar meydana getirebilir. Çalışanın maruz kaldığı tüm vücut titreşimi ise, titreşime sahip bir zeminde uzanma, ayaklar üzerinde durma veya oturma gibi farklı pozisyonlarda, kimi iş makinelerinin etrafında çalışma olduğunda, makine çalıştıran operatörlerde veya taşıma işlerinin hepsinde gerçekleşmektedir. Tüm vücudun üzerinde oluşturduğu titreşim maruziyeti, çalışan personelin iş yapma rahatlığını ve iş yapabilme kapasitesini düşürebilecek etkiye sahiptir. Tüm vücut titreşimine maruz kalan kişide, travmatik bir vaka'ya uğrayan omurga kalıcı bozukluklar oluşur [7]. Titreşim, insanların sağılığını etkileyen fiziksel kriterler arasında önemli bir yere sahiptir. İnsanlar iki tip titreşime maruz kalmaktadır. Bunlar; Tüm vücut titreşimi ve El-kol titreşimidir [8]. Tüm vücut 
titreşimi: Vücudun tamamına iletildiğinde çalışan insanın güvenliği ve sağlı̆̆ı açısından risk oluşturan, özellikle omurgada travmaya ve bel bölgesinde rahatsızlıklara sebep olan mekanik titreşimlerdir. El-kol titreşimi: İnsanda el-kol sistemine aktarıldığında, çalışan insanın güvenliği ve sağlığı için risk oluşturan ve eklem, kemik damar sinir ve kas bozukluklarına yola açan mekanik titreşimdir. Maruziyet eylem değeri: Aşıldığı durumda çalışanın titreşim maruziyetinden kaynaklanabilecek risklerin kontrol altına alınmasını gerektiren değerdir. Maruziyet sınır değeri ise: Çalışanların bu değer üzerinde bir titreşime kesinlikle maruz kalmaması gereken değeri ifade eder [9]. Üretimin sağlıklı devam etmesi ve çalışan operatörün, titreşimden kaynaklanan meslek hastalığına yakalanmaması için tüm vücut titreşimi için gerekli önlemler alınmalıdır. Tüm vücut titreşiminin en önemli giriş bölgeleri; kalça, ayaklar, başın arka tarafı ve sırt kısmıdır. Bu tür vibrasyondan etkilenen kişi ya ayaktadır veya oturuyordur. Çalışan oturuyor ise titreşim koltuktan veya sirt arkalığından girerken aslında ayaklar ve kalçadan vücuda girer. Ayakta duruyorsa, titreşim ayaktan vücuda girecektir. Bazen uçak, gemi gibi taşıma araçlarında yatar konumda olan kişiler de bu durumdan etkilenir. Böylesi bir durumda titreşimin sırttan vücuda girdiğinin kabul görmesi doğaldır [7]. İnsanda titreşim, kişinin titreşen bir yüzey ile direk teması sonucu oluşan ve kişi tarafından hissedilen titreşimdir. Bu yüzeyler; dövme tezgâhının kurulmuş olduğu zemin, otobüsün koltuğu veya enerji ile çalıştırılan el matkabının el ile tutulan bölgesi olabilir. İnsan vücuduna titreşimin etkileri oldukça ciddi olabilir. Kimi zamanlarda, belirli bir titreşim frekans ve seviyesine maruziyet, organlarda kalıcı hasarlara sebebiyet verebilir. Titreşim, iş veriminin düşmesinden konforsuzluk hissine kadar fiziksel hasarlara neden olabilir. İnsanların maruz kaldıkları titreşim seviyelerini zararsız hale getirmek için ölçüm ve analizleri yapılarak değerlendirmeye tabii tutmak gerekir [7]. Titreşim, her bir saniyede belirli bir saylya sahip olan ve tekrar eden dalgalara sahiptir. Titreşimin vücuda giriş yolları ise vücudun sert noktalarından girmesidir. Endüstrilerde, yoğun titreşimin meydana geldiği yüksek güç ile çalışan makinelerde oluşan titreşim, makineyi çalıştıran operatör üzerinde doğrudan etki göstermektedir. Titreşimin artışı işletme de kullanılan makinenin gücünün artışı ile de doğru orantılıdır [10]. Titreşim maruziyetine kalmış olan çalışanlarda zarar görme riski, titreşimin büyüklüğüne (dalga boyuna), etkilenen vücut bölgesine, frekansina ve maruziyet süresine göre değişiklik gösterir. Titreşimin olduğu herhangi bir işte çalışanın maruz kaldığı titreşim, bu etmenlere göre çalışanlar üzerindeki etkiler de farklılık gösterebilir [7]. Son zamanlarda dikkat çeken mesleki kas ve iskelet sistemi hastalıkları, çalışanın yapmış olduğu iş ile ilgili olduğu düşünülen meslek hastalıklarının dâhil edilmesini sağlamıştır. Mesleki kas ve iskelet sistemi hastalıkları, kol ve bacaklar, omuz, el kısımları, diz ve tendon, kas yapılarının devamlı olarak kullanılmasıyla nitelendirilir. Bu konuyu genel olarak analiz etmek için modellemek gerekirse; hareketlerin sıklığı, güç uygulanması, fiziksel duruşun zorlayıcı olması, iyileşme süresindeki yetersizlikler ve maruziyet süresinin uzun olması gibi belirli kriterlere odaklanılmalıdır. Titreşime sebep olan cihazların kullanımı, termal konfor şartlarının yetersizliği, kişisel koruyucu donanıma ihtiyaç duyulan işler yapmak gibi faktörler de bu analize eklenebilir [11]. Güçlendirilmiş el aletleri veya mekanik titreşime sebep olan işlemler, parmaklardan veya ellerin avuç içi tarafından vücuda giren titreşim olarak adlandırılır. El ile vücuda giren titreşimin diğer bir ismi de el-kol titreşimidir. Operatörün kullanmış olduğu güçlendirilmiş aletler birkaç sanayi kolunda yaygındır. Bunlar; (Vuruşlu metal çalışmaları, spiral taşlama makinası, öğütücü makineler, kaya delgi aletleri, ziraat tarım ve ormancılıkta kullanılan zincir testereler) olarak örneklendirilebilir. El-kol titreşimine aşırı derecede maruziyet, damarlarda, kaslarda, sinir ve eklem rahatsızlıklarına neden olabilmektedir [8]. Vücudun belli bir bölgesinde oluşan, genellikle el ve el parmaklar ile kollara ulaşan ve vücudun belli bir bölgesini etkileyen titreşime lokal titreşim etkisi denir. Endüstride, en çok karşılaşılan ve lokal titreşime neden olan araçlar taş kırma makinaları, pnömatik çekiçler, taşınabilir testere, parlatma ve rendeleme makinalarıdır. Lokal titreşime maruz kalmada olduğu gibi tüm vücudun titreşime maruz kalması da, çalışma konforunu ve çalışanların 
performanslarını olumsuz yönde etkiler. Tüm vücudu titreşime maruz bırakan titreşim kaynakları, konstrüksiyon ve çimento sanayi işletmeleridir. Tüm vücudun titreşime maruz kalması sonucunda; omurganın travmaya uğraması, bel ağrısı ve omurga dejenerasyonlarının artması, intervertebral disklerin (omurları birbirine birleştiren ana madde) kayması durumları gelişir. Bunların yanı sıra aynı durumda olan kişilerde, mide ağrısı, sindirim problemi, üriner zorluklar, denge bozukluğu, görme bozukluğu, baş ağrısı ve uykusuzluk gibi sağlık sorunlarının ortaya çıktığı gözlenmiştir [10]. Bu çalışma, İstanbul ilinde faaliyet gösteren bir dövme fabrikasında karşı vuruşlu çekiç tezgâhlardan kaynaklanan titreşim ölçümleri yapılmıştır. Dövme tezgâhlarında üretim yapılırken yüksek enerji kullanımından dolayı, operatöre etki eden titreşim maruziyeti söz konusu olmaktadır. Fabrikanın titreşime karşı aldığ1 önlemler araştırılmış ve uygulamalar yerinde gözlemlenmiştir. İşletmede yapılan titreşim ölçüm sonuçları iş sağlığı ve güvenliği kanununun titreşimden korunma yönetmeliğine göre karşılaştırılmıştır. Fabrikadaki çekiç tezgâhların çalışma esnasında titreşimi fabrika zeminine ulaştırmayı engelleyen sistem incelenmiştir.Bu çalışmada, bu kanun kapsamında çalışanların titreşimle ilgili risklerden korunmalarına dair yönetmeliğe bağlı olarak belirlenen sınır değerler dikkate alınarak dövme tezgâhlarında çalışanların maruz kaldıkları titreşim değerleri belirlenmiştir.

\section{Materyal ve yöntem}

\subsection{Yüksek Enerjili Dövme Makinalart}

Yüksek enerji ile çalışan dövme makineleri üç tipte üretilmektedir. Şekil 1' de dövme makinaları (tezgâhları) gösterilmektedir. Şekil 1a' da tek başlıklı tezgâh, Şekil 1b' de çift başl1klı dövme tezgâhı ve Şekil 1c' de kontrollü enerji akışlı tezgâh gösterilmektedir. Bu tezgâhların enerji seviyeleri şahmerdanlardan çok daha yüksektir[12].
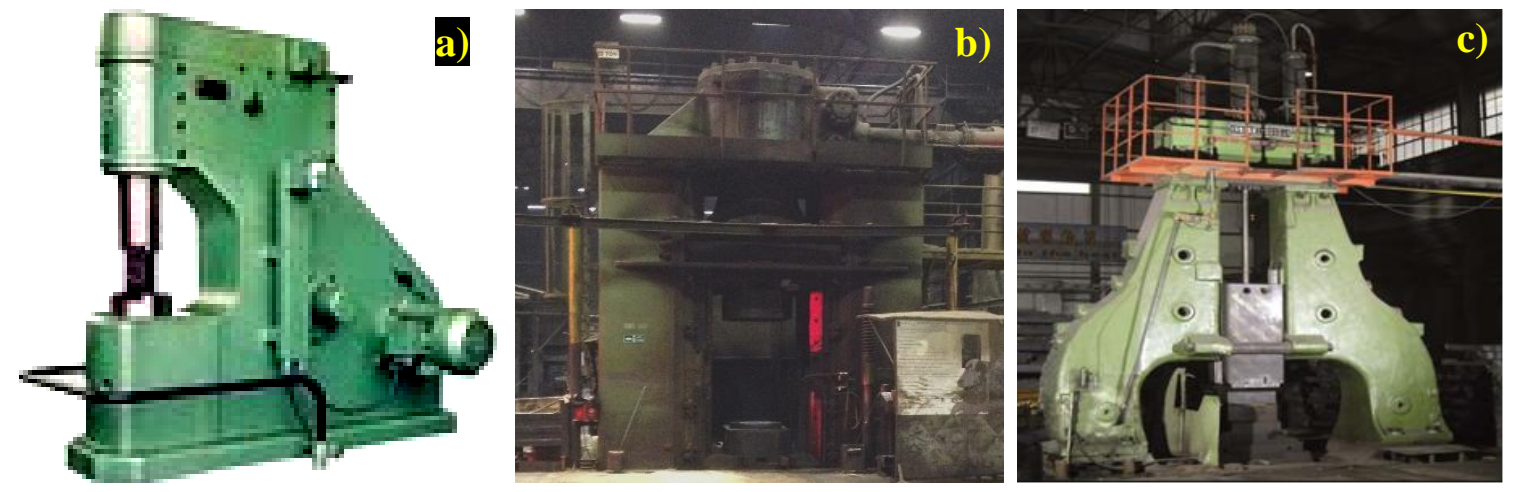

Şekil 1. Dövme Makinaları: a) Tek başlıklı tezgâh, b) Çift başlıklı dövme tezgâhı,

c) Kontrollü enerji akışlı tezgâh.

İşletmedeki çekiç tezgâhlara aylık, altı aylık ve yıllık olmak üzere belirli periyotlarda bakım ve kontrol yapılmaktadır. Böylelikle tezgâhlarda oluşabilecek arıza ile beraber insan sağlığını tehlikeye atabilecek durumlar oluşmadan rutin kontroller sayesinde gerekli bakım programları uygulanmış olmaktadır.

DG40 sıcak dövme tezgâhı ağırlık prensibine göre çalışmakla birlikte hem hidrolik hem de pnömatik sistem dövme tezgâhının koçlarının aşağı yukarı hareketini sağlamaktadır. Tezgâhın üst koç ağırlığı $48500 \mathrm{~kg}$ alt koç ağırlığı ise $51300 \mathrm{~kg}$ gelmektedir. Alt kalıp üst kalıp yüksekliği maksimum $550 \mathrm{~mm}$ olup kırlangıç derinliği $109 \mathrm{~mm}$ ve 5 derecelik bağlama 
açısına sahiptir. Koçlar pik dökümden imal edilmiş olup sertliği yaklaşık olarak $190 \mathrm{HB}$ (Brinell sertlik) değerindedir. Tezgâhın ağırlık prensibine göre çalışma esası; Alt koç ağırlığı +Alt kalıp ağırlığ $/$ Üst kalıp ağrılığ 1 Üst koç ağırlığ $1=\% 4$ ile $\% 8$ arasında olmalıdır. DG 40 tezgâhı bir darbe esnasında maksimum 40 ton metre kuvvetle darbe yapmaktadır. Operatörün tezgâh pedalına bastığı anda basınçlı hava üst kepte ilgili odalardan basınç noktasına ulaşarak üst koçu aşağı doğru iterek hareket ettirmektedir. Üst koç aşağı inerken üst koç ile bağlantılı olan hidrolik sistem alt koçun altında bulunan hidrolik tanktan basınç artışını sağlayarak alt tankın üzerinde bulunan alt koçun yukarı doğru hareket etmesini sağlayarak koçlar arasında karşı vuruş gerçekleşmektedir.

DG16 tezgâhı çalışma prensibi DG 40 tezgâhı ile aynı olup arasındaki farklar; üst koç ağırlığı $12125 \mathrm{~kg}$, alt koç ağıllı̆ğ $12825 \mathrm{~kg}$ 'dır. DG16 tezgâhı alt kalıp ve üst kalıp yüksekliği 450 mm' dir.

DIGEP 1600 tezgâhı hidrolik sistemle çalışmaktadır. Ana tanktaki hidroliğin basıncını arttırmak sureti ile hareketli olan üst tablayı aşağı doğru hareket ettirerek sabit olan alt tablada bağlı olan dövme sistemlerinde imalatı gerçekleştirmektedir. 1600 tonluk kuvvet üretmektedir.

1. ÖLÇÜM: Tesiste bulunan A isimli personel, DG16 grubu bölümünde çalışmakta iken tüm vücut titreşim ölçümleri yapılmıştır.

2. ÖLÇÜM: Tesiste bulunan B isimli operatör DG40 grubu bölümünde çalışmakta iken tüm vücut titreşim ölçümleri yapılmıştır.

3. ÖLÇÜM: Tesiste bulunan C isimli operatör DIGEP 1600 bölümünde çalışmakta iken tüm vücut ölçümü yapılmıştır.

\subsection{Kullanılan Ölçüm Yöntemleri ve Standartlar}

,Çalışmanın yapıldığı sıcak dövme işletmesi, İstanbul ilinde faaliyet gösteren, otomotiv ve ağır iş makinaları sektörüne yedek parça üreten bir metal dövme fabrikasıdır. İşletmede üç vardiyalı çalışma söz konusudur. Çekiç tezgâhlarda çalışan 3 operatöre etki eden titreşim ölçümleri ve önleme yolları incelenmiştir. İşletmedeki titreşim ölçümleri, Türk Standartları Enstitüsü, Mühendislik Hizmetleri Hazırlık Grubunca kurulan ilgili komite tarafindan hazırlanan standartların vücut titreşiminin ölçülmesi için "Mekanik Titreşim ve Şok - Tüm Vücut Titreşimine Maruz Kalma Değerlendirmesi - Bölüm 1, Genel Kurallar - TS ISO2631", ile "Mekanik Titreşim - Titreşim Emisyon Değerinin Belirlenmesi Amacıyla Hareketli Makinaların Deneye Tabi Tutulması - TS EN 1032 + A1” standartları kullanılmıştır.

\subsection{Titreşim Ölçümünde Kullanılan Cihaz ve Özellikleri}

Titreşim ölçümünde kullanılan cihaz C67 kodlu SVANTEK marka 958 model 11754 seri numaralı portatif gürültü ve vibrasyon ölçüm cihazıdır. Cihazın teknik bilgileri aşağıda verilmiştir. 


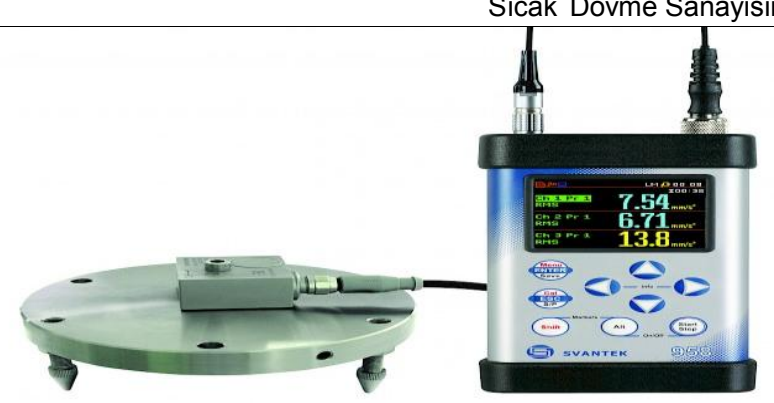

Şekil 2. Titreşim ölçümünde kullanılan cihaz

Ölçümlerin sayısal doğru RMS (Çalışanın max. ve min. titreşim efektif değeridir. Yani, Elinizi titreşim yapan bir makinaya koyduğunuzda hissettiğiniz titreşim değeridir.) dedektörleri ile çözünürlük $0,1 \mathrm{dBA}^{\prime}$ dır. Titreşim ölçümü $1 \mathrm{~s}$, 5s ve $10 \mathrm{~s}$ aralıklarla yapılmıştır. RMS frekans ağırlıklı ivme değerleri $\left(\mathrm{m} / \mathrm{s}^{2}\right)$ ve seviyeleridir $(\mathrm{dB}) . A(8)$ titreşim maruziyeti, 1-125 Hz oktav bantlarında belirli periyotlarda (1s, 5s, 10s) RMS ivme değerleri $\mathrm{m} / \mathrm{s}^{2}$ ve seviyesi $\mathrm{dB}$, ağırlıkları ile ağırlıklı hızlanma için histogramlar ve ağırlıklı hızlanma için yüzde değerleri eş zamanlı olarak ölçülmüsstür.

\subsection{Kullanilan Pres}

Çekiç tezgâhların kurulum aşamasında tezgâhın çalışabileceği temelde çelik yaylar üzerine özel olarak dökülen 600 tonluk beton sayesinde tezgâh ile işletme zemini arasında kurulan yaylı mesnet sönümleyici bir faaliyet göstermektedir. Tezgâh servis esnasında çekiç darbelerinden dolayı oluşan titreşimi en aza indirerek işletme zeminine ulaştırmaktadır. Özel beton ve yayların bakım onarım faaliyetleri de belirli periyotlarda kontrol altında tutularak gerek görüldüğü takdirde değissimleri ve onarımları yapılmaktadır. Yayların beton kütlenin altından çıkartılıp onarım altına alınması için; 600 tonluk beton kütlenin dört tarafına krikolar dengeli bir şekilde yerleştirmektedir. Kriko ile özel beton arasına krikonun betona yaptığ basıncı azaltmak için merkezi krikoya denk gelecek şekilde 30x400x400 mm' lik platina yerleştirilerek özel beton yayların üzerinden dengeli bir şekilde kaldırılmaktadır. Kaldırılan beton kütlenin altından hasarlı olan yaylı mesnetler yenisi ile değiştirilmektedir. Bu Arsoy’ un yapmış olduğu çalışma ile de örtüşmektedir [13].

Ön yüklemesi yapılmış olan yaylı yataklar, yapıların ve büyük makinaların titreşim yalıtımı için etkin olarak kullanılmaktadır. 600 tonluk beton kütlenin altında 400 adet yay kullanılmaktadır. Yaylı mesnetler yük desteği sağlarlar ve düşey/yatay yer değiştirmelerine imkân tanırlar. Yaylı mesnetler ek olarak viskoelastik bir sönümleyici de içerecek şekilde paket halinde tedarik edilmektedir. Her pakette 8 adet yay ve ortalarında bir adet viskoelastik sönümleyici sıvı olacak şekilde tezgâhın altında titreşimi sönümleyici etki etmektedir. İşletme genelinde çalışan personel ve çekiç tezgâh operatörlerinde dikkat çeken nokta gerekli kişisel koruyucu donanımın eksiksiz kullanımının sağlanması için takibinin yapılmasıdır.

İşletmede, iş sağlığı ve güvenliği ile ilgili eğitimlerin işe başlamada ve belirli periyotlarda operatörlere verilmesi iş sağlığı ve güvenliği kültürünün oluşması noktasında önemli yer tutmaktadir.

\section{Bulgular ve tartışma}

\subsection{Maruziyet Sınır ve Maruziyet Eylem Değerleri}

İş Sağlığı ve Güvenliği kanununda Çalışanların Titreşim ile İlgili Risklerden Korunmalarına Dair Yönetmeliğe göre; Tüm vücut titreşimi için; Sekiz saatlik mesai süresinde günlük maruziyet sınır değeri $1.15 \mathrm{~m} / \mathrm{s}^{2}$, Sekiz saatlik mesai süresi için günlük maruziyet eylem 
değeri ise; $0.5 \mathrm{~m} / \mathrm{s}^{2}$ olarak belirtilmiştir [9]. El kol titreşimi için ise: Sekiz saatlik çalışma süresi için günlük maruziyet sınır değeri: $5 \mathrm{~m} / \mathrm{s}^{2}$. Sekiz saatlik çalışma süresi için günlük maruziyet eylem değeri ise: $2.5 \mathrm{~m} / \mathrm{s}^{2}$ olarak belirlenmiştir [9].

Tablo 1. Maruziyet sınır ve eylem değerleri tablosu [9].

\begin{tabular}{|c|c|c|}
\hline \multirow{2}{*}{$\begin{array}{c}\text { Tüm vücut } \\
\text { titreşimi için }\end{array}$} & $\begin{array}{c}\text { Günlük maruziyet eylem } \\
\text { değeri }\end{array}$ & $\begin{array}{c}\text { Günlük maruziyet sınır } \\
\text { değeri }\end{array}$ \\
\cline { 2 - 3 } & $0,5 \mathrm{~m} / \mathrm{s}^{2}$ & $1,15 \mathrm{~m} / \mathrm{s}^{2}$ \\
\hline El kol titreşimi için & $2,5 \mathrm{~m} / \mathrm{s}^{2}$ & $5 \mathrm{~m} / \mathrm{s}^{2}$ \\
\hline
\end{tabular}

\subsection{Titreşime Maruz Kalan Operatörler, Yapılan İşin Tarifi ve Ölçüm Sonuçları}

$\mathrm{Bu}$ çalışmadaki kilit noktası, operatörlerin çalışmalarını yerine getirirken maruz kaldıkları titreşim değerlerini titreşim yönetmeliğinin belirlemiş olduğu değerlerin altına çekerek sağlıklı ve güvenli bir çalışma ortamını işletmeye ve operatörlere sunmaktır. Bu amacımızı gerçekleştirmek için 6331 sayılı İş Sağlığı ve Güvenliği kanunu kapsamında izlenecek yol aşağıda sıralamıştır.

1. İkame yöntemini seçmek.

2. Yapılan işe göre titreşimi en aza indiren kişisel koruyucu donanımı seçmek.

3. Oturma yerlerini ve el ile çalışılan aletlerde tutamaklar için titreşimi azaltan donanım sağlamak.

4. İşyeri ve makineler için uygun bakım programlarını devreye sokmak.

5. İşyeri tasarımını ve ortamını düzenlemek.

6. Mekanik titreşim maruziyetlerini azaltmak maksadı ile kişisel koruyucu donanımı güvenli ve doğru kullanım için gerekli eğitimleri vermek.

7. Maruziyet süresi ve seviyesini sinırlandırmak.

8. Çalışma sürelerini yeterli dinlenme aralarıyla düzenlemek.

9. Çalışanı nemden ve soğuktan koruyacak giysileri temin etmek [9].

Tablo 2. Tüm vücut titreşimi için ölçülen değerler.

\begin{tabular}{|c|c|c|c|c|c|c|}
\hline No & $\begin{array}{c}\text { Ölçüm } \\
\text { Yap1lan } \\
\text { Ünite }\end{array}$ & $\begin{array}{c}\text { Ölçüm } \\
\text { Personeli }\end{array}$ & $\begin{array}{c}\text { Ölçüm } \\
\text { Türü }\end{array}$ & $\begin{array}{c}\text { Titreşim } \\
\text { Değeri } \\
\text { ahv } \\
\left(\mathrm{m} / \mathrm{s}^{2}\right)\end{array}$ & $\begin{array}{c}\text { Toplam Titreşim } \\
\text { Değeri } \\
\mathrm{A}(8) \\
\left(\mathrm{m} / \mathrm{s}^{2}\right)\end{array}$ & $\begin{array}{c}\text { Maruziyet } \\
\text { Eylem } \\
\text { Değeri } \\
\left(\mathrm{m} / \mathrm{s}^{2}\right)\end{array}$ \\
\hline 1 & DG16 Grubu & $\mathrm{A}$ & \multirow{2}{*}{$\begin{array}{c}\text { Tüm vücut } \\
\text { titreşimi }\end{array}$} & 0,24 & 0,225 & 0,5 \\
\cline { 1 - 1 } & DG40 Grubu & $\mathrm{B}$ & 0,038 & 0,035 & 0,5 \\
\hline 3 & DIGEP 1600 & $\mathrm{C}$ & & 0,0224 & 0,21 & 0,5 \\
\hline
\end{tabular}

Tablo 1' de verilen bazı kısaltmaların açıklamaları; ahv: $\mathrm{m} / \mathrm{s}^{2}$ cinsinden ifade edilen, frekans ağırlıklı ivme değerinin toplam titreşim değeridir. Bu değer, üç eksende ölçülen titreşim için ahv değerlerinin karelerinin toplamının kareköküdür. A(8): 8 saatlik çalışma süresi için titreşime maruz kalma değeridir. 1. 2. ve 3. ölçümler: İşletmede bulunan A, B ve C isimli personellere, DG16, DG40 ve DIGEP1600 bölümlerinde sıcak metal parçalarına pres ile şekil veren çalışanlara tüm vücut titreşim ölçümleri yapılmıştır. Operatörler, pres makinası operatörü olarak çalışmaktadır. Titreşimler pres makinası tarafından kaynaklanmaktadır. Ölçüm noktası operatör alanı olup zemin betondur. Tesisin çalışma kapasitesi \% 70' dir. Operatörler iş ayakkabısı giymektedirler. Operatörler, 8 saatlik mesai süresi boyunca toplam 7 
saat kesikli olarak titreşime maruz kalmışlardır. Tablo 2' de 3 operatörden belirlenen tüm vücut titreşimi değerleri verilmiştir. Bu tablodaki sınır değer için "Çalışanların Titreşimle İlgili Risklerden Korunmalarına Dair Yönetmelik” kapsamında Maruziyet Eylem Değeri baz alınmıştır. Frekans, $0.5-20 \mathrm{kHz}$ aralığındadır. Yapılan ölçümler sonucun da Tablo 1' de görüldüğü üzere; DG 16 grubunda çalışan operatör için $\mathrm{A}(8)$ değeri 0.225 olarak ölçülmüş olup ölçülen değer operatörün tüm vücut titreşimi maruziyet eylem değerinin altında seyretmektedir. DG 40 ve DIGEP 1600 tezgâhlarındaki ölçüm sonuçları da sekiz saatlik çalışma süresi için $0.5 \mathrm{~m} / \mathrm{s}^{2}$ değerinin altında kalmıştır.

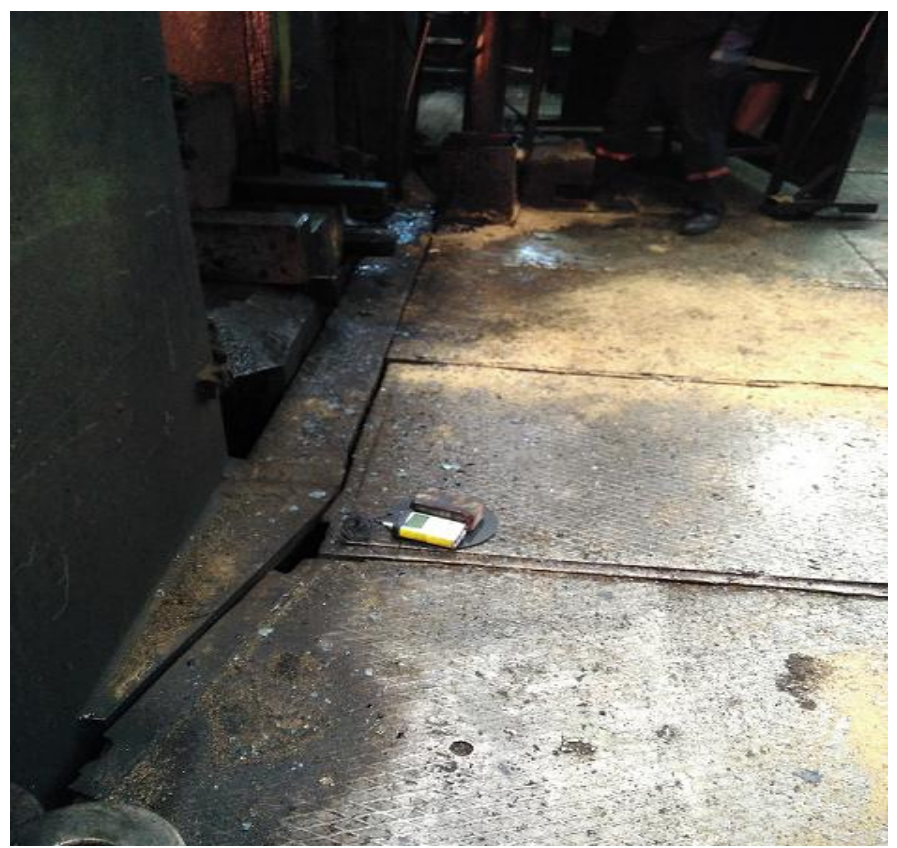

Şekil 3. Titreşim ölçümü yapıldığg andaki operatör ve tezgâhın konumunun resmi

Tüm vücut titreşim ölçümü yapılırken operatörlerin tezgâha göre duruş mesafesi Şekil 3' teki gibidir. Tüm vücut titreşim ölçümlerinde operatörler ayakta çalışmaktadır. Ölçüm cihazının aparatı operatörün ayakaltına konularak titreşim maruziyet ölçümü yapılmıştır. Tüm vücut titreşim ölçümü, tezgâh çalışırken 3' er dakikalık periyotlarda yapılmıştır. Operatörün gögüs kısmının ortası sıfır noktası kabul edilip omuzlara doğru X ekseni kafaya ve aşağı doğru Z ekseni sırt kısmı ve ön doğrultusu da Y ekseni olarak kabul edilmiştir.

\section{Sonuçlar}

Tesiste bulunan personel üzerinde üç farklı çalışma pozisyonunda yapılan tüm vücut titreşim ölçüm sonuçlarına göre; personelin maruz kaldığı titreşim değerinin yönetmelikte belirtilen maruziyet eylem değerinin altında olduğu tespit edilmiştir. İşletmede alınan proaktif çalışmalar sonucu hem tezgâhların çalışmalarında olumsuz bir olay ile karşılaşılmamakta hem de operatörlerin titreşim maruziyet değerleri zarar vermeyecek değerlerde tutulmaktadır. Çekiç tezgâhlarda tezgâhın pistonları ile işletme zeminini arasında kalan beton zemin ve yaylar sayesinde titreşim önemli derecede azaltılmaktadır. Gerekli önlemlerin alınması ve çalışma şartlarının iyileştirilmesi sonucunda dövme endüstrisinde çalışan operatörlerin maruz kaldıkları titreşim değerleri, insan sağlığına zarar vermeyecek niteliktedir. Dövme endüstrisinde özellikle tezgâh kurulum aşamasında titreşimin yapacağı etkiyi göz önüne alarak zemin etüdü yapılması ve mühendislik çalışmalarının bu yönde olması, titreşimi önemli ölçüde etkileyecek bir durumdur. İşletmelerin bu durumu önemle göz önünde bulundurma gerekliliği olmalıdır. İş sağlığı ve güvenliğinin proaktif yapısının önemi yapmış olduğumuz 
çalışmada da dikkat çekmektedir. Önceden alınan önlemler sayesinde, dövme sanayisinde çalışan operatörler için titreşim azaltılabilmekte çalışanın sağlığ 1 korunabilmektedir.

\section{Simgeler ve Kısaltmalar}

RMS: Yani, Elinizi titreşim yapan bir makinaya koyduğunuzda hissettiğiniz titreşim değeridir.

HB: (Brinell sertlik)

A(8): 8 saatlik çalışma süresi için titreşime maruz kalma değeridir.

ahv: $\mathrm{m} / \mathrm{s}^{2}$ cinsinden ifade edilen, frekans ağırlıklı ivme değerinin toplam titreşim değeridir.

\section{Referanslar}

[1] Demirkol, M., "Plastik Şekil Verme Ders Notları", İTÜ. Mak. Müh. Bölümü. İSTANBUL. 2010, ss.3.

[2] Çapan, L., "Dövülebilirlik, Açık Kalıpta Dövme", TMMOB Sanayi Kongresi ANKARA, 1991.

[3] Dövme (Forging), http://w3.balikesir.edu.tr/ ay/dersler/Dovme-Hadde-Extruzyon.pdf. Erişim Tarihi : 2016.

[4] Görgülüarslan, R. M., Güler, M. A., "Otomotiv Endüstrisinde Kullanılan S1cak Şekillendirme Tekniğinin İncelenmesi", Mühendis ve Makina, ANKARA; 2015, cilt 56, say1 660, ISSN 1300-3402, ss. 41-51.

[5] Çakır, G., Nas, E., "Orta Karbonlu AISI1040 İmalat Çeliğine Uygulanan Sıcak Dövme İşleminin Malzemenin Mekanik Özelliklerine Etkisi", İleri Bilimleri Teknolojisi, 2016, ISSN:2147-3455, Cilt5, Say1 1. ss 92-97.

[6] Yurci, M, E. "Kapalı Kalıpta Çapaklı Dövme", TMMOB Sanayi Kongresi, ss. 139 ANKARA, 1991.

[7] Zeyrek, S., "Titreşim", İş Sağlığı ve Güvenliği Uzmanlık Tezi, Çalışma ve Sosyal Güvenlik Bakanlığı, ANKARA, 2009.

[8] İşsever, H., "Vibrasyon ve İnsan Sağlığı Üzerindeki Etkileri", TMMOB İş sağlığı ve Güvenliği Konferansı Bildiriler Kitabı, ISBN: 975-395-357-7, İSTANBUL, 1999, ss 85-99.

[9] Çalışanların Titreşimle İlgili Risklerden Korunmalarına Dair Yönetmelik Yayımlandığı Resmi Gazete Tarihi/Sayıs1: 22.08.2013/28743 www.bilgit.com.

[10] Camkurt, M, Z. "İşyeri Çalışma Sistemi ve İşyeri Fiziksel Faktörlerinin İş Kazaları Üzerindeki Etkisi", TÜHSİS İş Hukuku Dergisi, ANKARA, 2007, cilt 20, say1 6, ss. $103,104$.

[11] Gedikli, F, G., "İş Yerinde Risk Değerlendirmesi ve Sonrasında Alınan Önlemlere Örnekler", İş Sağlığı ve Güvenliği Dergisi, ANKARA, 2011, sayı 51, ISSN: 1300-2341 ss. 44,45.

[12] Yurci, M, E., "Özel Yöntemler (Dövme Haddeleri, Yüksek Enerjili Dövme, Hassas Dövme) ", TMMOB Makine Mühendisleri Odası İstanbul Șubesi Plastik Șekillendirme Kalıp Tasarımı - III Dövme Teknolojisi Seminer Notları, İSTANBUL, 1991, ss. 211.

[13] Arsoy, S. "Dövme Çekici Tipi Bir Makine Temelindeki Titreşimlerin Azaltılması", Zemin Mekaniği ve Temel Mühendisliği 1. Özel Konulu Sempozyum, 2007. 